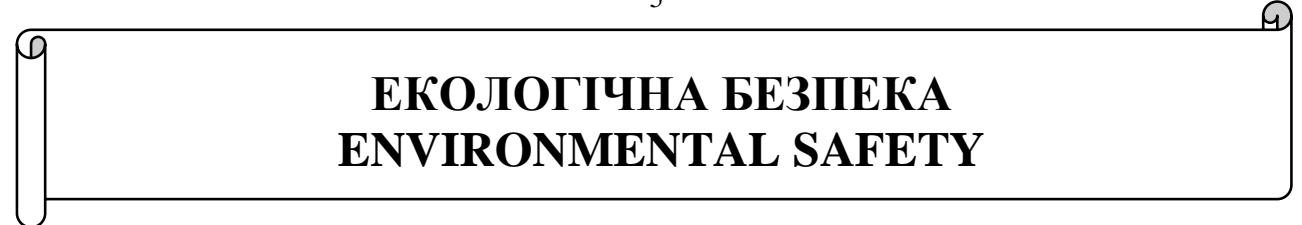

UDC 504.064.2

Tetyana I. Kryvomaz ${ }^{1}$, D. S., Professor of the Department of Labour and Environment Protection

ORCID ID: 0000-0002-4161-9702 e-mail: ecol@i.ua

Nina S. Karpenko², student

e-mail: kandirynina@gmail.com

${ }^{1}$ Kyiv National University of Construction and Architecture, Kyiv, Ukraine

${ }^{2}$ National University of «Kyiv-Mohyla Academy», Kyiv, Ukraine

\title{
GREEN STANDARDS FOR IMPROVING OFFICE ACTIVITIES IN NEW CONDITIONS
}

\begin{abstract}
The pandemic COVID-19 and quarantine have forced companies to restructure their office work for efficiency increase in crisis situations. Green standards can help, because they have harmonious combination of environmental, economic and social aspects. Recommendations for restructuring office work include reorganization of work schedules with the expansion of work from home, virtual meetings with using modern communication technologies, re-equipment of office space according to the requirements of social distance, innovative measures to improve working conditions and indoor environmental quality, new rules of interaction in public places, strengthening hygiene and disinfection of premises to improve safety. The application of green standards in office activities reduces the negative impact of the organization on the environment, promotes efficient management of resources and energy saving, optimizes procurement and waste management, improves the quality and comfort of the indoor environment, save health and efficiency of employees, which has a positive impact on economic and the company's reputation.

Key words: green office; green certification; pandemic; environmental safety
\end{abstract}

\section{T.I. Кривомаз ${ }^{1}$, Н.С. Карпенко ${ }^{2}$}

${ }^{1}$ Київський національний університет будівництва та архітектури, м. Київ, Україна

${ }^{2}$ Національний університет «Києво-Могилянська академія», м. Київ, Україна

\section{ЗЕЛЕНІ СТАНДАРТИ ДЛЯ ПОКРАЩЕННЯ ОФІСНОЇ ДІЯЛЬНОСТІ В НОВИХ УМОВАХ}

Анотація. Пандемія COVID-19 та карантин змусили компанії перебудувати офісну діяльність для ефективної роботи в кризових умовах. При цуьому зелені стандарти можуть виступати у ролі орієнтира, оскільки гармонічне

(C) Т.I. Кривомаз, Н.С. Карпенко, 2020

ISSN: 2411-4049. Екологічна безпека та природокористування, № 2 (34), 2020 
поєднання екологічних, економічних та сочіальних аспектів завжди залишається актуальним. Рекомендації по перебудові офісної роботи включають реорганізачію робочих графіків з розширенням можливостей дистаниійної праиі, проведення безконтактних нарад та зустрічей 3 використанням сучасних технологій зв'язку, переобладнання офісного простору з урахуванням вимог сочіальної дистаниії, інноваційних заходів по покращенню умов праці і робочого мікроклімату, нових правил взаємодії у місиях загального користування, посилення норм гігієни та дезінфекиіі приміщень для підвищення безпеки. Застосування зелених стандартів в офісній діяльності зменшує негативний вплив організаиії на довкілля, сприяє ефективному управлінню ресурсами та енергозбереженню, оптимізує закупівлі та поводження з відходами, підвищує якість $i$ комфорт внутрішнього середовища приміщень, покращує стан здоров'я та прачездатність прачівників, що водночас позитивно відображається на економічних та репутаційних показниках компанії.

Ключові слова: зелений офіс; зелена сертифікачія; пандемія; екологічна безпека

\section{Вступ}

Глобальні проблеми навколишнього середовища сьогодні стосуються всіх без винятку і у сучасному конкурентному суспільстві турбота про довкілля $\epsilon$ необхідною передумовою функціонування будь-якої організації [8]. Жодна компанія не може залишатись осторонь від вирішення проблем навколишнього середовища, оскільки вони безпосередньо впливають на життя кожної людини i обумовлюють перспективи розвитку бізнесу. Соціально відповідальний бізнес за усіма параметрами випереджає неетичний бізнес, особливо у довгостроковій перспективі [3]. Концепція зеленого офісу спрямована на зменшення негативного впливу на навколишнє середовище офісної діяльності компанії шляхом максимального збереження ресурсів та енергії і зменшення кількості відходів. Принципи зеленого офісу може застосовувати будь-яка компанія, незалежно від сфери іiі діяльності, фінансових можливостей та кількості працівників [19]. Впровадження правил зеленого офісу в корпоративну культуру компанії допомагає не тільки змінити ставлення кожного співробітника до збереження навколишнього середовища на роботі, але й поширювати набуті знання і звички в родині та соціальному оточенні. Крім того, в концепції зеленого офісу багато уваги приділяється підвищенню комфорту умов праці та якості внутрішнього середовища офісних приміщень, а також збереженню здоров'я співробітників, що безпосередньо впливає на продуктивність їх праці та загальний успіх компанії.

Актуальність концепції зеленого офісу обумовлена тим, що 50\% загального енергоспоживання приходиться на офісні приміщення, при цьому 21\% використаної офісами енергії витрачається даремно, а 2/3 3 цього - у неробочий час [14]. Близько 60\% викидів парникових газів, пов'язаних із роботою типового офісу, припадає на системи опалення, кондиціонування та вентиляції [32]. Щороку кожен офісний працівник продукує 120-140 кг відходів, 3/4 з яких становить паперове сміття [20]. Навіть розвиток цифрових технологій не супроводжується значним зниженням споживання паперу, і до того ж 25\% документів викидаються через 5 хвилин після їх роздрукування, a $16 \%$ роздруківок навіть ніхто ніколи не читає [15]. Поширений стереотип 
щодо несуттєвого впливу віртуальної реальності на навколишнє середовище не відповідає дійсності, оскільки цифрові технології також вносять значну частку у загальне забруднення, зокрема, із загального об'єму викидів парникових газів, пов'язаних 3 цією галуззю, 25\% припадає на центри опрацювання даних, $28 \%$ - на інфраструктуру, $47 \%$ - на обладнання користувачів [18]. Для виробництва комп'ютера вагою 2 кг використовується 800 кг сировини, при цьому на кожні 169 кг сировини припадає 124 кг викидів $\mathrm{CO}_{2}$ [27]. Суттєвий негативний вплив на довкілля також спричиняють транспортні переміщення офісних працівників, внаслідок яких загалом утворюється 12 мегатонн викидів $\mathrm{CO}_{2}$ [31]. Таким чином, мінімізація негативного впливу на навколишнє середовище офісної діяльності є одним 3 пріоритетних напрямків розвитку провідних компаній, особливо тих, які ведуть свою діяльність в узгодженні з критеріями корпоративної соціальної відповідальності бізнесу. Пандемія COVID-19 та необхідність переходу на карантин змусили компанії переосмислити принципи організації робочого процесу, і в цей період у нагоді стали принципи зеленого офісу. Очевидно, що відтепер робота компаній потребує докорінної перебудови і розробка нових рекомендацій з організації офісної діяльності із застосуванням принципів зеленого офісу набуває особливої актуальності.

\section{Постановка завдання}

Зважаючи на необхідність перебудови принципів організації робочого процесу в офісах у зв'язку з пандемією COVID-19, надзвичайної актуальності набуває концепція зеленого офісу, яка потребує доопрацювання з урахуванням нових вимог у світі глобальних соціальних та економічних змін. Виходячи 3 вищевикладеного, мета даної роботи полягає у розробці практичних рекомендацій для організації праці офісних працівників на основі зелених стандартів в умовах пандемії COVID-19 та у пост-пандемічний період. В узгодженні з даною метою сформульовано такі завдання:

- проаналізувати підгрунтя та особливості зеленої сертифікації офісних приміщень для зниження негативного впливу організації на довкілля водночас $з$ підвищенням рентабельності компанії;

- визначити сфери перетину інтересів учасників процесу впровадження зелених офісних стандартів для різних груп зацікавлених осіб в українських компаніях;

- обгрунтувати економічні та нематеріальні переваги зелених стандартів для визначення цінностей офісних будівель;

- визначити ключові міжнародні тенденції розвитку офісної діяльності та представити інструменти адаптації цих практик в діяльність вітчизняних організацій;

- розробити поетапні рекомендації та окреслити заходи безпеки та комфорту ефективного функціонування офісу в умовах пандемії COVID-19 та у пост-пандемічний період 3 урахуванням зменшення негативного впливу на довкілля. 


\section{Результати досліджень}

Формування концепції зеленого офісу почалося з 70-х років минулого століття за часів глобальної нафтової кризи, коли провідні компанії США і Західної Європи були вимушені вдатися до заходів корпоративної економії [14]. Перший зелений офіс було створено у 1984 р. в США для Агентства по захисту навколишнього середовища, коли єдиний на той момент моніторинг якості повітря офісних приміщень був проведений за гроші R.J. Reynolds Tobacco Company i то тільки для того, щоб довести «нешкідливість пасивного куріння на робочому місці» [10]. А вже у 1987 р. в документі Комісії ООН по економічному розвитку «Наше загальне майбутнє» прем'єр-міністр Норвегії Гру Харлем Брунтланд запропонувала таке визначення: «Зелений офіс - це філософія управління організацією, яка дозволяє зменшити негативний вплив діяльності компаній шляхом максимального збереження ресурсів і енергії і оптимізації кількості відходів у навколишнє середовище» [35]. 3 тих часів було пройдено довгий шлях для усвідомлення необхідності дбайливого ставлення бізнесу до довкілля та здоров'я людей, але детально концепцію зеленого офісу було розроблено WWF у Фінляндії тільки в 2002 р. [38]. Аналітик Томас Фрідман вважає, що переломний момент стався у 2006 р., коли «зелена ідея» і «зелений спосіб життя» досягли масовості, а відтоді проекти, інвестиції і виробництво за зеленими принципами стали сприйматися критичною масою людей як нова норма сучасності [17].

В Україні науковим та практичним аспектам зеленого офісу присвячено праці Алексєєнко О.А., Бурковської А.В., Геворкян А.Ю., Головко О.Н., Данилової Н.В., Дубодєлової А.В., Ковальова Б.Л., Лункіної Т.I., Маслюківської О.П., Матвєєвої Ю.Т., Мосійчук І.В., Паламарчук К.О., Петрашко Л.П., Рубан А.В., Шпак О.Г., Шульги H.I., Шульженко I.В., Яковенко А.О. та інших авторів, а з кожним роком ця тема набуває все більшої актуальності $[1,2,3,4,5,7,8]$. Концепція екологічного управління українськими організаціями офісного типу у 2012 році трансформувалася у стандарт СОУ.ОЕМ 08.036.067:2012 «Зелений офіс. Екологічні критерії та метод оцінювання життєвого циклу», який був розроблений національним технічним комітетом стандартизації ТК 82 «Охорона довкілля». Стандарт базується на кращих практиках впровадження зелених офісів у поєднанні 3 критеріями міжнародних систем оцінки будівель LEED, BREEAM, DGNB i містить чіткі показники, яким має відповідати зелений офіс $[11,34,36]$. Процедура оцінки відповідності стандарту «Зелений офіс» проводиться за схемою екологічної сертифікації згідно з ISO 14024, а ISO 14001 визначає механізм впровадження та функціонування ефективної системи екологічного менеджменту [24]. Крім того, екологічна сертифікація організацій за програмою «Зелений офіс» також передбачає проведення оцінки відповідності організацій офісного типу стандарту СОУ ОЕМ.08.036.067 «Адміністративні послуги (офіси). Екологічні критерії» і охоплює такі аспекти, як ефективне управління матеріальними та природними ресурсами, енергозбереження, якість оточуючого середовища робочої зони, поводження 3 відходами, закупівлі товарів і послуг [6]. Відповідно до «Настанови щодо екологічної сертифікації та маркування «зелений офіс» для програм екологічного маркування I типу згідно з ДСТУ ISO 14024» сертифікація відбувається за такими категоріями: 
1. Екологічний менеджмент.

2. Енергоефективність.

3. Споживання води.

4. Збереження тепла.

5. Поводження з відходами.

6. Автотранспортні засоби.

7. Товари, вироби та послуги, що закуповуються.

8. Інформування.

Сертифікація зелених офісів дозволяє ідентифікувати і контролювати екологічні аспекти діяльності організації, їі продукцію та послуги, знижувати негативний вплив організації на навколишне природне середовище, зберігаючи при цьому рентабельність виробництва [2]. В розвинутих країнах для урядових установ та провідних компаній світу зелена сертифікація стає необхідною умовою оренди офісу [16]. Схема екологічного менеджменту та аудиту СС (EMAS) Свропейської Комісії охоплює всі сфери економіки і послуг в усьому світі та підтримує організації у пошуку перевірених інструментів зниження показників негативного впливу на навколишнє середовище [1]. Сертифікати зеленого офісу видає також Greenpeace, якщо немає перевірених інструментів зниження показників негативного впливу на навколишнє середовище [4]. Логотип зеленого офісу WWF (Фінляндія) свідчить про корпоративну відповідальність компанії, вдосконалене управління екологічною ефективністю, впровадження заходів 3 енергозбереження та практичні ініціативи по підвищенню екологічної обізнаності співробітників [38]. Але при цьому Greenpeace та WWF не висувають чітких кількісних вимог до показників функціонування офісів, а тільки стимулюють розвиток культури впровадження зелених офісів та виконують інформативно-просвітницьку функцію [2]. Окремої уваги заслуговують системи зеленої сертифікації BREEAM (Великобританія), DGNB (Німеччина) та LEED (США), які визначають якість та вплив будівлі на довкілля ще на етапах планування, проектування, будівництва, експлуатації, реконструкції, перебудови та зносу споруди в кінці іiі життєвого циклу. Такий комплексний підхід забезпечує раціональне землекористування, економію природних ресурсів та енергії, ефективність водокористування, скорочення забруднення та шкідливих викидів, високу якість внутрішнього середовища, безпеку та комфорт людей, інновації та постійне вдосконалення $[11,34]$.

Для ефективного впровадження зелених стандартів в офісну діяльність слід враховувати потреби та інтереси різних цільових груп. Виділено принаймні три категорії осіб, які прямо або опосередковано впливають на успіх реалізації проектів зеленого офісу в життя: 1) власники офісних приміщень; 2) керівники компаній, що орендують офіси; 3) співробітники компаній та відвідувачі офісів. Крім того, особливості проекту будівлі та інфраструктура залежать від забудовника. На перший погляд інтереси всіх перелічених категорій зацікавлених осіб знаходяться у конфліктних співвідношеннях: забудовник прагне побудувати дешевше i продати дорожче, власник хоче купити найкращу нерухомість за мінімальні кошти і здавати ऑii в оренду за максимальними ставками, орендарі мріють про високу якість приміщень за найменшими цінами, а користувачі в першу чергу звертають увагу на комфорт. Водночас, завдяки реалізації концепції зеленого офісу, можливо знайти сфери перетину інтересів всіх стейкхолдерів офісних приміщень (рис. 1). 


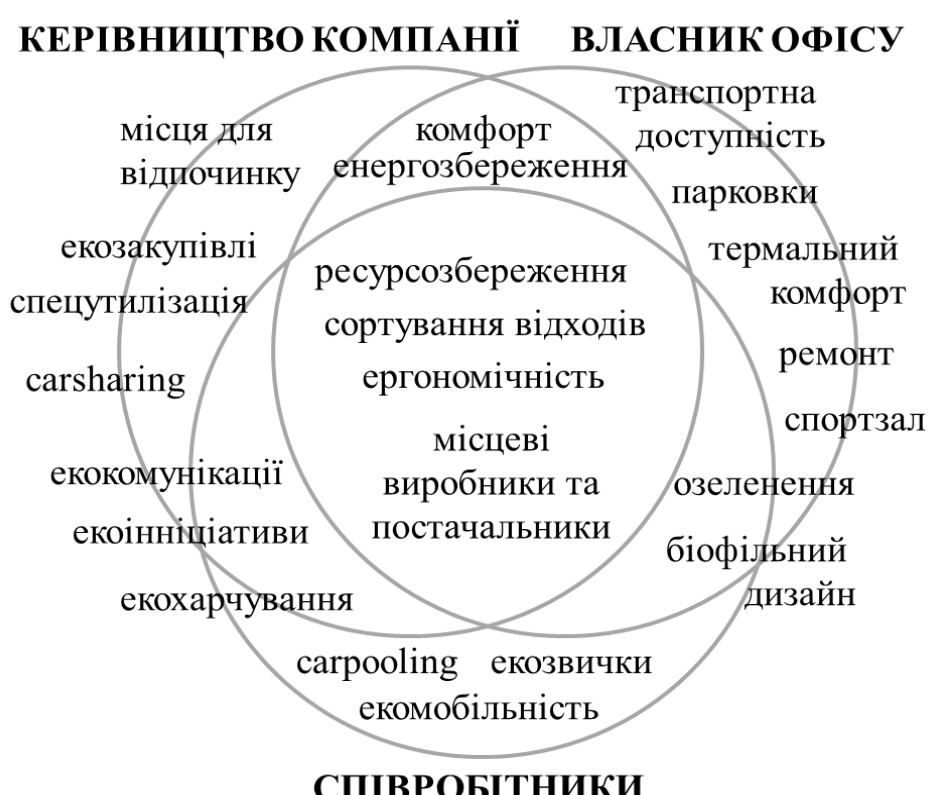

Рис. 1 - Сфери перетину інтересів учасників процесу впровадження зелених офісних стандартів

Проектні рішення забудовників впливають на енергоефективність приміщень, тепловий, акустичний та візуальний комфорт, характеристики матеріалів, що використовуються в процесі будівництва. В результаті дослідження 10000 офісних будівель в США виявлено, що вартість зеленої будівлі приблизно на 5,5 мільйонів доларів більше, ніж вартість звичайної будівлі в тому ж районі [16]. Проте німецькі дослідники довели, що кожне євро, вкладене у збереження ресурсів, окупається в 2-3 рази [2]. Однією 3 найбільших економічних переваг зеленої сертифікації будівель вважають економію витрат на електроенергію. У типовій офісній будівлі енерговитрати становлять 30\% загальних експлуатаційних витрат будинку, тому серед орендарів та власників офісних приміщень зростає попит на зелені споруди. Однак окремі дослідження експлуатаційних витрат ряду офісних будівель США не підтверджують прямого взаємозв'язку зеленої сертифікації та економії енергії, що може бути наслідком індивідуального підходу до операційних витрат кожного орендаря [12]. Власники офісних приміщень можуть бути зацікавлені збільшенням ставок орендної плати в зелених офісах у порівнянні зі звичайними приміщеннями. Цікаві дослідження були проведено для виявлення зв'язку переваг зеленої сертифікації будівель та політичних уподобань, внаслідок чого з'ясувалося, що на політичноліберальних територіях націнки на оренду зелених офісів становлять майже $6 \%$, а у політично консервативних - менше 2\% [21]. У сертифікованих зелених офісах Великобританії орендна ставка вища на 3\% за квадратний фут, надбавки за ефективну оренду вище $6 \%$, а ціни на продаж зелених будівель вище приблизно на 16\%. При цьому енергоефективне проектування при зниженні споживання енергії на 10\% підвищує собівартість всього на 1\%, що повністю відшкодовує підвищену плату за оренду та зелену сертифікацію 
офісних будівель [28]. Навіть в країнах, що розвиваються, зелені офіси набувають все більшого поширення. Наприклад, в Малайзії внески інвесторів в зелені офісні будівлі позитивно впливають на такі фактори рентабельності інвестицій (Return on investment - ROI), як підвищення капіталу, більший дохід від оренди та економію витрат, а також сприяють підвищенню попиту та числа пропозицій зеленої нерухомості в країні, що мінімізує ризики та забезпечує повернення інвестицій [23].

Беззаперечні достовірні докази економічних переваг зелених будівель пов'язані не тільки 3 енергозберігаючими характеристиками, підвищенням орендної плати та продажної ціни, а також 3 нематеріальними аспектами зеленої сертифікації, які також відіграють значну роль у визначенні цінностей зелених будівель на ринку [16]. Недарма зелену сертифікацію за стандартами BREEAM та LEED в Україні в першу чергу отримали саме офісні центри, які тепер завдяки видатним характеристикам якості користуються великим попитом на оренду серед провідних міжнародних та українських компаній. До нематеріальних наслідків сертифікації відносять підвищення продуктивності працівників та покращення іміджу компанії, що також впливає на визначення ринкової вартості зелених будівель [32]. Тому необхідними атрибутами зеленого офісу $є$ не тільки засоби зниження навантаження на довкілля, але й забезпечення комфорту та якості внутрішнього середовища, які безпосередньо впливають на здоров'я та працездатність людей. I це також впливає на економічні показники компанії, наприклад, завдяки зеленій сертифікації офісу штаб-квартири Genzyme i пов’язане з цим збільшення продуктивності праці, вдалося зекономити понад 2 млн \$ на рік зарплатного фонду [11].

В середньому офісний працівник проводить близько 200 днів на рік в офісі, а 80\% всіх захворювань виникають під впливом середовища та способу життя [29]. За визначенням ВОЗ здоров'я - це «стан повного фізичного, розумового і соціального благополуччя, а не тільки відсутність захворювань» [37]. Серед офісних захворювань, пов'язаних 3 непрацездатністю, 7\% відносять до скелетно-м'язових пошкоджень, а 1/3 лікарняних видаються через болі у попереку [36]. В зелених офісах рівень працездатності підвищується на 8-11\% за рахунок зменшення захворюваності та покращення умов праці, кількість прогулів зменшується на 10\%, рівень комфорту оцінюють на $13 \%$ вище і на $23 \%$ зменшується частота виникнення випадків головного болю та подразнення очей $[11,15]$. Дотримання вимог якості внутрішнього середовища в приміщенні (indoor environmental quality - IEQ) $є$ ключовим фактором добробуту та продуктивності офісних працівників. В результаті порівняння IEQ зелених та звичайних будівель в Китаї і Тайвані виявлено, що користувачі зелених офісів значно вище оцінюють тепловий та акустичний комфорт, вентиляцію та якість повітря, дизайн та оздоблення приміщень, умови праці та стан здоров'я, у порівнянні з працівниками звичайних офісних приміщень [29, 30]. Свіже повітря в офісах $є$ одним 3 ключових показників якості внутрішнього середовища, оскільки при збільшенні концентрації $\mathrm{CO}_{2}$ від 700 pрm до 1000 pрm продуктивність та якість робочого процесу знижується на 11-23\% [22]. В оцінці відчуття комфорту слід враховувати гендерну специфіку офісних працівників, оскільки встановлено, що жінки більш чутливі до зниження температур, особливо взимку [12]. Дотримання стандартів зеленого офісу призводить не тільки до збереження природних ресурсів, але й до підвищення продуктивності праці та добробуту людей [25]. 
В залежності від визначення сфер відповідальності та можливостей, формуються рекомендації по впровадженню зеленого офісу на різних рівнях працівники, керівництво і менеджмент компанії, орендодавець. Керівники та менеджмент компаній зацікавлені у підвищенні продуктивності праці співробітників та економії ресурсів, що витрачаються на функціонування компанії. Саме вони приймають рішення про закупівлі, організацію праці. I, нарешті, найбільша категорія стейкхолдерів зеленого офісу - це безпосередньо самі співробітники компанії. Їх приваблює комфорт та якість робочої зони, позитивний вплив зеленого офісу на своє здоров'я та робочий графік. В окремих європейських країнах впровадження принципів зеленого офісу навіть рекомендовано профспілковими організаціями, оскільки це сприяє створенню більш безпечного і комфортного робочого середовища, внаслідок чого усуваються шкідливі умови для розвитку ряду професійних захворювань [28]. Головні переваги для працівників зеленого офісу - це підвищення комфорту та збереження здоров'я, для роботодавців - зростання працездатності співробітників, а для власників офісу - престиж та підвищення орендних ставок. У згаданих вище категорій осіб, зацікавлених у впровадженні зеленого офісу, є зони перетину інтересів. Наприклад, і орендодавці, і орендарі зацікавлені в економії енергії та підвищенні престижу офісного приміщення. Умови праці безпосередньо пов'язані зі здоров'ям користувачів, тому висока якість і комфорт робочих приміщень вигідні і керівництву, і співробітникам компанії.

Епідемія COVID-19 та карантин змусили компанії переосмислити підходи до роботи, при цьому стало очевидно, що застосування принципів зеленого офісу може допомогти навіть у такій надзвичайній ситуації. В умовах пандемії і глобальної економічної кризи офісна діяльність потребує перебудови, а набутий досвід може стати у нагоді після завершення карантину, оскільки вже зараз стало очевидним, що людство перейшло в нову еру, де спалахи смертельних інфекційних захворювань стають повсякденною реальністю. Для виживання необхідно змінити правила соціальної взаємодії та умови праці, а трудове законодавство в Україні не мінялось з радянських часів і там немає згадок про віддалену працю, крім надомної роботи для інвалідів. Проте наприкінці 2019 р. у парламент було внесено законопроект № 2708 «Про працю» та ще три альтернативних проекти, і у 2020 р. українці очікують новий закон, який дозволить офіційно формувати гнучкий графік роботи, працювати дистанційно та ще багато чого. Такий підхід відповідає вимогам часу i потребує розробки рекомендацій для функціонування офісів у постпандемічний період.

Рекомендовано перебудувати систему організації роботи з урахуванням індивідуальних особливостей працівників, які виявляться після аналізу продуктивності праці з дому під час карантину. Надання роботодавцями своїм співробітникам можливості працювати 3 дому та організація гнучкого робочого графіку не тільки підвищує продуктивність праці, але й сприяє економії енергії та ресурсів, а також позитивно впливає на довкілля за рахунок зменшення транспортного забруднення. Все більше компаній та державних установ в усьому світі надають перевагу дистанційній праці. А під час пандемії 2020 року цей підхід набув особливої актуальності та зберіг здоров'я і життя багатьох людей. Скоординований план роботи працівників дозволяє спланувати нову стратегію робочого простору та врахувати індивідуальні 
особливості продуктивності працівників. В узгодженні з новими вимогами серед перевірених ефективних стратегій організації робочого простору рекомендовано такі: 1) відокремлені індивідуальні робочі місця; 2) офісний простір для спільної роботи невеликих груп з урахуванням норм соціальної дистанції; 3) домашній офіс; 4) робочі місця спільного користування за принципом вільного столу для співробітників, які не знаходяться в офісі постійно.

Концепція flex-office передбачає гнучкі графіки, роботу з дому, коворкінг, мобільність на робочому місці. Згідно з дослідженням провідної компанії у сфері нерухомості CBRE, 46\% французьких компанії все ще розташовані в стандартних закритих офісах, але зростають тенденції переходу найбільших корпорацій у flex-office, причому навіть до пандемії протягом останніх п'яти років таку організацію офісного простору обрали Paribas Personal Finance, L'Oréal, Sanofi, BETC, SFR, Engie, PSA, Danone, Crédit Agricole i Bouygues [15]. Тобто, незважаючи на те, що на сьогодні flex-office займає тільки 6\% ринку офісної нерухомості Франції, тут акумульовано 17\% співробітників великих компаній, які при цьому демонструють найвищий рівень задоволення умовами праці. Опитування включало 46\% співробітників звичайних закритих офісів, $27 \%$ фрілансерів, 8\% працюючих вдома та 6\% у флекс-офісі [27]. Прогресивні організації переглянули свою політику стосовно віддаленої праці персоналу, наприклад, у Twitter співробітникам дозволили не повертатися у офіс навіть після закінчення карантину. Під час пандемії виявилось, що більшість офісних працівників можуть ефективно виконувати свої обов'язки з дому, а 75\% нарад та переговорів можна проводити дистанційно 3 використанням сучасних технологій зв'язку. До того ж режим дистанційної праці є проявом родинноорієнтованої корпоративної культури, що покращує продуктивність працівників та сприяє їх нематеріальній мотивації. Зменшення кількості ділових поїздок та ефективне використання цифрових комунікацій для дистанційної праці та віртуальних зустрічей економить час та зменшує викиди у зовнішнє середовище від транспортних засобів.

В компаніях, де не всі працівники повний робочий день знаходяться в офісі, у більшості співробітників немає фіксованих робочих місць і діє принцип чистого столу, коли після робочого дня зі столу прибирають особисті речі. Метод для роботи великих команд sharing desk полягає в тому, що кожного ранку співробітники самі вирішують, де їм сьогодні розміститися і займають будь-яке вільне робоче місце. В офісах з незакріпленими робочими місцями hotdesking у працівників немає особистого простору, але в той же час весь простір належить їм.

Офіси типу open space забезпечують динамічний простір для працівників та кращий контроль підлеглих для керівників. Відкритий офісний простір покращує взаємодію між співробітниками, але при цьому важко зосередитись та сконцентруватись, а це незадовільно впливає на якість роботи, швидкість виконання завдань та процес запам'ятовування. В умовах пандемії і у постпандемічний період офіси відкритого типу бажано замінити індивідуальними робочими відсіками, що легко зробити за допомогою мобільних перегородок. Такий підхід дозволяє більш ергономічно використовувати офісний простір, створюючи різноманітні локації для комунікацій, нарад, конференцій, навчання, прийому їжі, відпочинку та спортивних занять. Для забезпечення мобільності простору також застосовують трансформовані меблі, завдяки 
чому кімнату для переговорів можна легко перетворити на лекторій, тренінгзал або зону для офіційної зустрічі. В залежності від функціональності і для забезпечення акустичного комфорту використовують різні типи перегородок. Скляними перегородками GlassSystem обладнують кімнати для переговорів i нарад, а перегородки Haworth поглинають до 70\% шуму, тому їх встановлюють між робочими столами. Але навіть такі заходи не завжди бувають ефективними, адже $60 \%$ працівників за столами 3 перегородками і 50\% людей, які працюють в ореn space, незадоволені акустичним комфортом, натомість тільки 16\% власників окремих кабінетів страждають від зайвих шумів [22]. Крім перегородок, акустичний офісний комфорт забезпечують спеціальні пристрої та матеріали, наприклад, килимове покриття Interface не лише має високі показники звукопоглинання та звукоізоляції, але й на $80 \%$ складається 3 повторно перероблених матеріалів. Не всі працюють ефективно в умовах ізоляції, навіть в індивідуальних кабінетах деякі люди почуваються самотньо і їм здається, що вони відірвані від колективу. Тому в офісах створюють комфортні умови для роботи невеликих команд від 2 до 16 людей в одній кімнаті, де вони можуть взаємодіяти, але рівень шуму значно нижче. Слід пам'ятати, що офіс - це не тільки місце для роботи, але й середовище для життя і спілкування. Необхідно знайти баланс і забезпечити співробітникам умови для вільного вибору, попередньо дослідивши взаємозв'язок продуктивності праці та типу офісного простору і робочого графіку.

Транспортна доступність та район розташування офісу все ще домінують серед факторів офісного престижу, але дизайн інтер'єру офісів набуває все більшого значення. До сучасних актуальних тенденцій обладнання офісу відносять біофільний дизайн, що передбачає інтеграцію природних елементів в будівлі для позитивного впливу на здоров'я та добробут людей. Це може проявлятись як у формі озеленення зовні та всередині будівель, так і у використанні різноманітних природних елементів в інтер'єрах для забезпечення оздоровчого та естетичного ефектів. Опитування 1000 французьких студентів покоління Ү виявило, що 42\% можуть відмовитись від запропонованої роботи, якщо офісне середовище буде недостатньо «зеленим» [27]. Біофільний офіс включає не тільки наявність зелених рослин в офісі, але й природну естетику, кольори, освітлення, звуки, різноманітність, текстуру поверхонь та вид 3 вікон. У співробітників офісів з зеленими рослинами $\mathrm{i}$ природним освітленням на 6\% збільшується продуктивність та на $15 \%$ креативність, крім того, покращується стан здоров'я та зменшується кількість прогулів [11]. Зелені стіни з рослин покращують акустику в офісі, знижують рівень $\mathrm{CO}_{2}$ та поглинають шкідливі летючі сполуки. Найкращими для офісного комфорту вважаються заспокійливі пастельні тони в інтер'єрі. Проте у проведеному експерименті з оцінки впливу кольору стін на продуктивність та настрій працівників було отримано несподівані результати. Суб'єктивна оцінка піддослідних суперечила результатам тестування, оскільки спочатку респонденти стверджували, що червоний колір стін їх відволікає, а білий більше підходить для офісної праці. Але при виконанні тестового завдання найменше помилок офісні працівники робили у приміщенні, пофарбованому у червоне, а у білій кімнаті - найбільше [26]. Таким чином, офісні приміщення потребують різноманіття дизайну та кольорів i згідно 3 результатами досліджень білі кімнати підходять для рутинної праці, червоні - для напруженої роботи, а зелені - для відпочинку. В умовах небезпеки поширення 
інфекції у дизайні офісних інтер'єрів слід надавати перевагу матеріалам 3 поверхнею, що легко дезінфікується. Рекомендовано впровадження нових норм прибирання приміщень та правил поводження у спільних офісних просторах. Для підвищення безпеки необхідно створити умови для дотримання соціальної відстані на робочих місцях, у ліфтах, холах, конференцзалах, приймальнях, кухнях, їдальнях, вбиральнях тощо.

Співробітник, який почувається комфортно на робочому місці, завжди більш мотивований i ефективний, тому для залучення особливо цінних спеціалістів роботодавці намагаються створити найкращі умови для їх праці. Для сьогоднішніх випускників університетів фактор якості умов праці $\epsilon$ вирішальним у виборі роботодавця, але також велике значення мають зміст та кінцеві цілі самої роботи. Аудиторська фірма Deloitte провела дослідження «Sense au travail», внаслідок якого з'ясувалося, що для 30\% з 2500 респондентів найбільше значення має сенс роботи та організація праці, чверть пов'язують свій вибір з корпоративними цінностями і стільки ж - 3 командною роботою. Тільки для $2 \%$ опитаних найбільше значення має продукт компанії, для $5 \%$ сфера діяльності і для 12\% - вибір професії [28]. Представники молодого покоління схильні часто змінювати місце роботи, адже професійна мобільність пов'язана 3 прагненням до самовдосконалення і постійним пошуком кращого місця для самореалізації. Згідно з дослідженням 2018 р. «Les perceptions de la mobilité professionnelle» 43\% працівників змінили місце роботи (посаду, компанію, галузь, місто або країну) і 62\% 3 них задоволені новим вибором [31]. Щороку професійна мобільність збільшується на 5\%, і що ж очікують працівники від роботодавця? Опитування співробітників провідних європейських компаній показало, що 67\% з них очікують кращих умов праці, зокрема гнучкого графіку, зручного офісу і ефективних комунікацій; $36 \%$ бідкаються $з$ приводу поганого покриття Wi-Fi i GSM в офісній будівлі; 30\% звертають увагу на забезпечення харчуванням; 10\% - сподіваються на оплату житла; 9\% - потребують спортзал в офісі; 7\% - турбує безпека праці; 5\% розраховують на дитсадок всередині або поблизу офісу [9]. Але слід відзначити, що 58\% респондентів навіть не підозрювали про можливість отримання на роботі всіх перелічених переваг. Компанії, які зацікавлені у висококваліфікованих i талановитих співробітниках дефіцитних спеціальностей, вже сьогодні намагаються зробити все можливе для створення найкомфортніших умов праці, а концепція зеленого офісу якнайкраще підходить для досягнення цієї мети.

Пандемія COVID-19 та карантин змусили компанії переглянути принципи організації праці, і тому для ефективної роботи в кризових умовах необхідно перебудувати офісну діяльність, при цьому зелені стандарти можуть виступати у ролі орієнтира. Концепція зеленого офісу в нових умовах також потребує трансформації, але гармонічне поєднання екологічних, економічних та соціальних принципів завжди залишається актуальним. Критерії екологічної безпеки зеленого офісу підрозділяються на 2 основні категорії: 1) позитивний вплив на людей, що передбачає турботу про здоров'я і покращення комфорту співробітників компанії та відвідувачів офісу; 2) дбайливе відношення до навколишнього середовища шляхом зменшення загального негативного впливу. До головних принципів зеленого офісу відносять зменшення споживання природних ресурсів, скорочення забруднення довкілля, впровадження заходів енергоефективності, покращення умов праці, 
екологічна оптимізація закупівель, відповідальне поводження з відходами, раціональні транспортні комунікації, популяризація зеленого стилю життя. Впровадження концепції зеленого офісу призведе до корінних змін в офісному управлінні, зміцнить екологічну відповідальність, зменшить забруднення довкілля, підвищить продуктивність праці та прибутковість організацій. Застосування зелених стандартів дозволяє компанії вийти на кардинально вищий рівень розвитку з новою корпоративною культурою та згуртованою ідейною командою, яка здатна оперативно вирішувати найскладніші завдання бізнесу. Крім того, покращений соціальний імідж компанії дозволяє отримати значні нематеріальні вигоди в суспільстві завдяки зміцненню репутації серед клієнтів, партнерів, інвесторів, органів влади та широких кіл громадськості.

\section{Висновки}

1. Застосування зелених стандартів в офісній діяльності зменшує негативний вплив організації на довкілля, сприяє ефективному управлінню ресурсами та енергозбереженню, оптимізує закупівлі та поводження з відходами, підвищує якість i комфорт внутрішнього середовища приміщень, покращує стан здоров'я та працездатність працівників, що водночас позитивно відображається на економічних та репутаційних показниках компанії.

2. Для ефективного впровадження зелених принципів слід враховувати потреби різних цільових груп та знаходити сфери перетину інтересів учасників процесу, зважаючи на економічні та нематеріальні аспекти, зокрема: підвищення рентабельності інвестицій, збільшення попиту на оренду, зростання орендної плати та продажної ціни, зниження операційних витрат, мінімізація ризиків, підвищення продуктивності працівників та покращення іміджу компанії.

3. Пандемія COVID-19 та карантин змусили компанії перебудувати офісну діяльність для ефективної роботи в кризових умовах, при цьому зелені стандарти можуть виступати у ролі орієнтира, оскільки гармонічне поєднання екологічних, економічних та соціальних аспектів завжди залишається актуальним, а впровадження концепції зеленого офісу призведе до корінних змін в організації робочого процесу, зміцнить екологічну відповідальність, зменшить забруднення довкілля, підвищить продуктивність праці та прибутковість організацій, що дозволить компанії вийти на кардинально вищий рівень розвитку 3 новою корпоративною культурою та згуртованою ідейною командою, яка здатна оперативно вирішувати найскладніші завдання бізнесу.

4. Рекомендації по перебудові офісної роботи в період пандемії COVID-19 включають реорганізацію робочих графіків 3 розширенням можливостей дистанційної праці, проведення безконтактних нарад та зустрічей 3 використанням сучасних технологій зв'язку, переобладнання офісного простору з урахуванням вимог соціальної дистанції, інноваційних заходів 3 покращення умов праці і робочого мікроклімату, нових правил взаємодії у місцях загального користування, посилення норм гігієни та дезінфекції приміщень для підвищення безпеки. 


\section{СПИСОК ЛІТЕРАТУРИ}

1. Геворкян А.Ю. Безпаперовий офіс в українських реаліях на прикладі компанії ПАТ" САН ІнБев Україна" / А.Ю. Геворкян, А.В. Каплун, О.С. Локтіонова // Вісник НТУ «ХПІ». - 2018. - № 48(1324). - С. 100-103.

2. Данилова Н.В. Концепція «зеленого офісу»: світовий досвід та економічне обгрунтування для України / Н.В.Данилова // Modern Economics [Електронне наукове видання з економічних наук]. - 2017. - № 3. - С. 60-68.

3. Концепція зеленого офісу: Рекомендації для організацій щодо екологічного дружнього ставлення до навколишнього середовища / робоча група: О. П. Маслюківська та ін. - К.: Унів. вид-во «Пульсари», 2007.— 64 с.

4. Маслюківська О. Зелений офіс: з турботою про довкілля, з вигодою для бізнесу / О. Маслюківська, Ю. Щербініна, І. Сіваш - К.: Представництво ООН в Україні, 2009. $51 \mathrm{c}$.

5. Матвєєва Ю.Т. Обгрунтування необхідності впровадження принципів зеленого офісу в сучасних вищих навчальних закладах / Ю.Т. Матвєєва, Є.І. Перепека, О.А. Самофалова // Матеріали Міжнародної науково-практичної конференції «Економічні проблеми сталого розвитку» імені проф. Балацького О. Ф. (Суми, 11-12 травня 2016 р.) Міністерство освіти і науки України / Сумський державний університет (Україна). - С. 43-45.

6. Настанова щодо екологічної сертифікації та маркування «зелений офіс» для програм екологічного маркування I типу згідно ДСТУ ISO 14024 / Орган з сертифікації всеукраїнської громадської організації «Жива планета» [Електронний ресурс]. - 2012. 26 c. - Режим доступу : https://www.ecolabel.org.ua/images/page/nastanova-zeleniy-ofis2015.pdf. - Назва з екрана. - Дата перегляду: 23.04.2020.

7. Петрашко Л. П. Адаптація міжнародної практики «Зелений офіс» в українських компаніях / Л. П. Петрашко // Вісник Національного університету водного господарства та природокористування. Серія: Економіка : зб. наук. пр. / Нац. ун-т водного госп-ва та природокористування ; редкол.: В. А. Гурин (голов. ред.) [та ін.]. Рівне : НУВГП, 2010. - Вип. 4(52). - С. 180-185.

8. Шульженко І.В. «Зелений офіс» як інноваційна практика управління організацією / I.В.Шульженко // Менеджмент XXI століття: глобалізаційні виклики: [кол. монографія]. / [за заг. ред. проф. І. А. Маркіної] - Полтава : ТОВ Сімон, 2017. - С. 693700 .

9. Agence de la transition écologique (ADEME) [Електронний ресурс]. - Режим доступу : https://www.ademe.fr. - Назва з екрана. - Дата перегляду: 30.03.2020.

10. Braungart M. Cradle to Cradle: Remaking the Way We Make Things // M. Braungart, W. McDonough. - Farrar Straus \& Giroux : North Point Press, 2002. - 193 p.

11. Building Research Establishment Environmental Assessment Method (BREEAM) [Електронний ресурc]. - Режим доступу : https://www.breeam.com. - Назва 3 екрана. Дата перегляду: 23.04.2020.

12. Choi J.-H. Post-occupancy evaluation of 20 office buildings as basis for future IEQ standards and guidelines / J.-H. Choi, V. Loftness, A. Aziz // Energy and Buildings. - 2012. № 46. - P. 167-175.

13. Collinge W.O. Productivity metrics in dynamic LCA for whole buildings: Using a postoccupancy evaluation of energy and indoor environmental quality tradeoffs / W.O. Collinge, A. E. Landis, A. K. Jones, L. A. Schaefer, M. M. Bilec // Building and Environment. - 2014. № 82. - P. 339-348.

14. Eco-Management and Audit Scheme (EMAS) [Електронний ресурс]. - Режим доступу : www.ec.europa.eu/environment/emas/index_en.htm. - Назва з екрана. - Дата перегляду: 23.04.2020.

15. Écoresponsable au bureau. Actions efficaces et bonnes résolutions. - 2019. - Angers : ADEME. - 27 p. - [Електронний ресурс]. - Режим доступу : https://www.ademe.fr/sites/ 
default/files/assets/documents/guide-pratique-ecoresponsable-au-bureau.pdf - Назва 3 екрана. - Дата перегляду: 23.04.2020.

16. Eichholtz P. Doing Well by Doing Good? Green Office Buildings / P. Eichholtz, N. Kok, J.M. Quigley // American Economic Review. - 2010. - № 100 (5). - P. 2492-2509.

17. Friedman T. L. The power of green // The International Herald Tribune. - 2007. - April 15 [Електронний ресурс]. - Режим доступу : https://www.nytimes.com/2007/04/15/ opinion/15iht-web-0415edgreen-full.5291830.html. - Назва з екрана. - Дата перегляду: 23.04.2020.

18. Green Code Lab [Електронний pecypc]. - Режим доступу : https://www.greencodelab.org. - Назва з екрана. - Дата перегляду: 23.04.2020.

19. Green Office Guide egeneration [Електронний ресурс]. - Режим доступу : http://www.egeneration.co.uk/centre/modules/green_office. - Назва 3 екрана. - Дата перегляду: 23.04.2020.

20. Green office guide: A guide to help you buy and use environmentally friendly office equipment. [Електронний pecypc]. - 2001. - Commonwealth of Australia. - 22 p. - Режим доступу : http://www.energyrating.gov.au/library/pubs/greenofficeguide.pdf. - Назва 3 екрана. - Дата перегляду: 23.04.2020.

21. Harrison D. The political economy of green office buildings / D. Harrison, M. Seiler // Journal of Property Investment and Finance. - 2011. - V. 29 (4-5). - P. 551-565.

22. Hodgson M. Acoustical Evaluation of Six 'Green' Office Buildings / M. Hodgson, C. Eng // Journal of Green Building. - 2008. - № 3 (4). - P. 108-118.

23. Isa M. Factors affecting Green Office Building Investment in Malaysia Procedia / M. Isa, M. Rahman, I. Sipan, T.K. Hwa // Social and Behavioral Sciences. - 2013. - № 105. P. 138-148.

24. ISO 14040-14044: Environmental management - Life cycle assessment. - 2006. Geneve: Principles and framework, International Organisation for Standardisation (ISO).

25. Kamaruzzaman S.N. The effect of indoor environmental quality on occupants' perception of performance: A case study of refurbished historic buildings in Malaysia / S. N. Kamaruzzaman, C.O. Egbu, E. M. Ahmad Zawawi, A. S. Ali, A. I. Che-Anid // Energy and Buildings. -2011 . - V. 43(2-3). - P. 407-413.

26. Kwallek N. Effects of environmental colour on males and females: A red or white or green office / N. Kwallek, C.M. Lewis // Applied Ergonomics. - 1990. - V 21(4). - P. 275278.

27. La Semaine Européenne de la Réduction des Déchets (SERD) [Електронний ресурс]. Режим доступу : https://www.serd.ademe.fr. - Назва 3 екрана. - Дата перегляду: 23.04.2020.

28. Le label des PME qui s'engagent pour l'environnement (EnVol) [Електронний ресурс]. Режим доступу : www.envol-entreprise.fr. - Назва 3 екрана. - Дата перегляду: 23.04.2020.

29. Liang H.-H. Satisfaction of occupants toward indoor environment quality of certified green office buildings in Taiwan / H.-H. Liang, C.-P. Chen, R.-L. Hwang, W.-M. Shih, S.-C. Lo, H.-Y. Liao // Building and Environment. - 2014. - № 72. - P. 232-242.

30. Pei Z. Comparative study on the indoor environment quality of green office buildings in China with a long-term field measurement and investigation / Z. Pei, B. Lin, Y. Liu, Y. Zhu // Building and Environment. - 2015. - № 84. - P. 80-88.

31.Plan de Déplacements Entreprise [Електронний ресурс]. - Режим доступу : www.ademe.fr/sites/default/files/assets/documents/ademe_affiches_pde.pdf. - Назва 3 екрана. - Дата перегляду: 23.04.2020.

32. Robinson S. Which Green Office Building Features Do Tenants Pay For? A Study of Observed Rental Effects / S. Robinson, R. Simons, E. Lee // Journal of Real Estate Research. - 2017. - Vol. 39 (4). - P. 467-492.

33. Simons R. Green Office Buildings: A Qualitative Exploration of Green Office Building Attributes. / R. Simons, S. Robinson, E. Lee // Journal of Sustainable Real Estate. - 2014. Vol. 6(2). - P. 211-232. 
34. The Leadership in Energy \& Environmental Design (LEED) [Електронний ресурс]. Режим доступу : https://www.usgbc.org/leed. - Назва 3 екрана. - Дата перегляду: 23.04.2020.

35. United Nations (UN) [Електронний ресурс]. - Режим доступу : https://www.un.org. Назва з екрана. - Дата перегляду: 23.04.2020.

36. World Green Building Council (WGBC) [Електронний ресурс]. - Режим доступу : http://www.worldgbc.org/what-green-building. - Назва 3 екрана. - Дата перегляду: 23.04.2020.

37. World Health Organization (WHO) [Електронний ресурс]. - Режим доступу : https://www.who.int. - Назва з екрана. - Дата перегляду: 23.04.2020.

38.WWF, Всесвітній фонд природи [Електронний ресурс]. - Режим доступу : https://wwf.ua. - Назва з екрана. - Дата перегляду: 23.04.2020.

Стаття надійшла до редакиії 27.04.2020 і прийнята до друку після рецензування 28.05.2020

\section{REFERENCES}

1. Hevorkian, A.Yu., Kaplun, A.V., \& Loktionova, O.S. (2018). Bezpaperovyi ofis v ukrainskykh realiiakh na prykladi kompanii PAT" SAN InBev Ukraina" [The paperless office in ukraininan realities on the example of the PJCS "SUN InBev Ukraine" company]. Visnyk NTU «KPI», 48(1324), 100-103. (in Ukrainian)

2. Danylova, N.V. (2017). Kontseptsiia «zelenoho ofisu»: svitovyi dosvid ta ekonomichne obgruntuvannia dlia Ukrainy ["Green office" concept: international practices and economic evaluation for Ukraine]. Modern Economics, 3, 60-68. (in Ukrainian)

3. Masliukivska, O.P. at al. (2007). Kontseptsiia zelenoho ofisu: Rekomendatsii dlia orhanizatsii shchodo ekolohichnoho druzhnoho stavlennia do navkolyshnoho seredovyshcha [The concept of a green office: Recommendations for organizations on environmental friendliness]. Kyiv: Univ. vyd-vo «Pulsary». (in Ukrainian)

4. Masliukivska, O., Shcherbinina, Yu., \& Sivash, I. (2009). Zelenyi ofis: $z$ turbotoiu pro dovkillia, $z$ vyhodoiu dlia biznesu [Green office: with care for the environment, with benefits for business]. K.: Predstavnytstvo OON v Ukraini. (in Ukrainian)

5. Matvieieva, Yu.T., Perepeka, C.I., \& Samofalova, O.A. (2016). Obgruntuvannia neobkhidnosti vprovadzhennia pryntsypiv zelenoho ofisu $\mathrm{v}$ suchasnykh vyshchykh navchalnykh zakladakh [Substantiation of the need to implement the principles of green office in modern higher education institutions]. In Mizhnarodna naukovo-praktychna konferentsia "Ekonomichni problemy staloho rozvytku» imeni prof. Balatskoho O. F. Proceedings of the Conference, Sumy, May 11-12 2016. (pp. 43-45). Sumy: Sumskyi derzhavnyi universytet. (in Ukrainian)

6. Nastanova shchodo ekolohichnoi sertyfikatsii ta markuvannia «zelenyi ofis» dlia prohram ekolohichnoho markuvannia I typu zghidno DSTU ISO 14024. (2012). Orhan z sertyfikatsii vseukrainskoi hromadskoi orhanizatsii «Zhyva planeta». Retrieved 23 April 2020 from: https://www.ecolabel.org.ua/images/page/nastanova-zeleniy-ofis-2015.pdf. (in Ukrainian) 7. Petrashko, L.P. (2010). Adaptatsiia mizhnarodnoi praktyky «Zelenyi ofis» v ukrainskykh kompaniiakh [Adaptation of the international practice "Green Office" in Ukrainian companies]. Visnyk Natsionalnoho universytetu vodnoho hospodarstva ta pryrodokorystuvannia. Seriia: Ekonomika : zb. nauk. pr., 4(52), 180-185. (in Ukrainian)

8. Shulzhenko, I.V. (2017). «Zelenyi ofis» yak innovatsiina praktyka upravlinnia orhanizatsiieiu ["Green Office" as an innovative management practice of the organization]. Menedzhment KhKhI stolittia: hlobalizatsiini vyklyky. I.A. Markina (Ed.) Poltava: TOV Simon. (in Ukrainian)

9. Agence de la transition écologique (ADEME) (n.d.) Retrieved 30 March 2020, from: https://www.ademe.fr. 
10. Braungart, M., \& McDonough, W. (2002). Cradle to Cradle: Remaking the Way We Make Things. Farrar Straus \& Giroux: North Point Press.

11. Building Research Establishment Environmental Assessment Method (BREEAM). Retrieved 23 April 2020 from: https://www.breeam.com.

12. Choi, J.-H., Loftness, V., \& Aziz, A. (2012). Post-occupancy evaluation of 20 office buildings as basis for future IEQ standards and guidelines. Energy and Buildings, 167-175.

13. Collinge, W.O., Landis, A.E., Jones, A.K., Schaefer, L.A., \& Bilec, M.M. (2014). Productivity metrics in dynamic LCA for whole buildings: Using a post-occupancy evaluation of energy and indoor environmental quality tradeoffs. Building and Environment, 82, 339-348.

14. Eco-Management and Audit Scheme (EMAS). (2020). Retrieved 23 April 2020 from: http://www.ec.europa.eu/environment/emas/index_en.htm.

15. Écoresponsable au bureau. Actions efficaces et bonnes résolutions. (2019). Angers: ADEME. Retrieved 23 April 2020 from: https://www.ademe.fr/sites/default/files/assets/ documents/guide-pratique-ecoresponsable-au-bureau.pdf.

16. Eichholtz, P., Kok, N., \& Quigley, J.M. (2010). Doing Well by Doing Good? Green Office Buildings. American Economic Review, 100(5), 2492-2509.

17. Friedman, T. (2007). The power of green. The International Herald Tribune. Retrieved 23 April 2020 from: https://www.nytimes.com/2007/04/15/opinion/15iht-web-0415edgreenfull.5291830.html.

18. Green Code Lab. Retrieved 23 April 2020 from: https://www.greencodelab.org.

19. Green Office Guide egeneration. Retrieved 23 April 2020 from: http://www.egeneration.co.uk/centre/modules/green_office.

20. Green office guide: A guide to help you buy and use environmentally friendly office equipment. (2001). Commonwealth of Australia. Retrieved 23 April 2020 from: http://www.energyrating.gov.au/library/pubs/greenofficeguide.pdf.

21. Harrison, D., \& Seiler, M. (2011). The political economy of green office buildings. Journal of Property Investment and Finance, 29(4-5), 551-565.

22. Hodgson, M., \& Eng, C. (2008). Acoustical Evaluation of Six 'Green' Office Buildings. Journal of Green Building, 3(4), 108-118.

23. Isa, M., Rahman, M., Sipan, I., \& Hwa, T.K. (2013). Factors affecting Green Office Building Investment in Malaysia Procedia. Social and Behavioral Sciences, 105, 138-148.

24. ISO 14040-14044: Environmental management - Life cycle assessment. (2006). Geneve: Principles and framework, International Organisation for Standardisation (ISO).

25. Kamaruzzaman, S.N., Egbu, C.O., Ahmad Zawawi, E.M., Ali, A.S., \& Che-Anid A.I. (2011). The effect of indoor environmental quality on occupants' perception of performance: A case study of refurbished historic buildings in Malaysia. Energy and Buildings, 43(2-3), 407-413.

26. Kwallek, N., \& Lewis, C.M. (1990). Effects of environmental colour on males and females: A red or white or green office. Applied Ergonomics, 21(4), 275-278.

27. La Semaine Européenne de la Réduction des Déchets (SERD). Retrieved 23 April 2020 from https://www.serd.ademe.fr.

28. Le label des PME qui s'engagent pour l'environnement (EnVol). Retrieved 23 April 2020 from: www.envol-entreprise.fr.

29. Liang, H.-H., Chen, C.-P., Hwang, R.-L., Shih, W.-M., Lo, S.-C., \& Liao, H.-Y. (2014). Satisfaction of occupants toward indoor environment quality of certified green office buildings in Taiwan. Building and Environment, 72, 232-242.

30. Pei, Z., Lin, B., Liu, Y., \& Zhu Y. (2015). Comparative study on the indoor environment quality of green office buildings in China with a long-term field measurement and investigation. Building and Environment, 84, 80-88.

31. Plan de Déplacements Entreprise. Retrieved 23 April 2020 from: www.ademe.fr/sites/default/files/assets/documents/ademe_affiches_pde.pdf. 
32. Robinson, S., Simons, R., \& Lee, E. (2017). Which Green Office Building Features Do Tenants Pay For? A Study of Observed Rental Effects. Journal of Real Estate Research, 39(4), 467-492.

33. Simons, R., Robinson, S., \& Lee, E. (2014). Green Office Buildings: A Qualitative Exploration of Green Office Building Attributes. Journal of Sustainable Real Estate, 6(2), 211-232.

34. The Leadership in Energy \& Environmental Design (LEED). Retrieved 23 April 2020 from: https://www.usgbc.org/leed.

35. United Nations (UN). Retrieved 23 April 2020 from: https://www.un.org.

36. World Green Building Council (WGBC). Retrieved 23 April 2020 from: http://www.worldgbc.org/what-green-building.

37. World Health Organization (WHO). Retrieved 23 April 2020 from: https://www.who.int. 38. WWF, Vsesvitnii fond pryrody. Retrieved 23 April 2020 from: https://wwf.ua.

The article was received 27.04.2020 and was accepted after revision 28.05.2020

\section{Кривомаз Тетяна Іванівна}

доктор технічних наук, кандидат біологічних наук, професор кафедри охорони праці та навколишнього середовища Київського національного університету будівництва та архітектури

Адреса робоча: 03037 Україна, м. Київ, проспект Повітрофлотський, 31

e-mail: ecol@i.ua

ORCID ID: 0000-0002-4161-9702

\section{Карпенко Ніна Сергіївна}

студентка Національного університету «Києво-Могилянська академія» Адреса робоча: 04655 Україна, м. Київ, вулиця Григорія Сковороди, 2 e-mail: kandirynina@gmail.com 